\title{
Pedagogiken och lärarna
}

\author{
Ingrid Carlgren
}

Många ser antagligen pedagogikämnet som läraryrkets teoretiska kunskapsgrund. Relationen mellan universitetsämnet pedagogik och lärarutbildningen har dock alltid varit ansträngd. Även om lärarutbildningens behov var ett viktigt motiv för inrättandet av den första professuren i pedagogik i början av 1900-talet, har pedagogikämnet inte utvecklats till att bli den kunskapsbas läraryrket behöver. Bland annat genom att pedagogikforskningen $i$ stor utsträckning ägnat sig åt utbildningsfrågor snarare än undervisning, framstår pedagogikdisciplinen mer som politikers och policyaktörers vetenskap än lärarnas. Lärarutbildningen och universitetspedagogiken är i stor utsträckning skilda världar och även om det undervisas i pedagogik på lärarutbildningarna så är det något annat än universitetsdisciplinen pedagogik. Detta skapar en oklarhet angående innebörden i pedagogik, som förutom universitetsdisciplinen pedagogik kan syfta på pedagogiken i lärarutbildningen eller olika pedagogiska skolor. En annan aspekt är att den oklara situationen försvårar utvecklingen av en för läraryrket egen och självständig kunskapsbas. Eftersom det finns en föreställning om att en sådan redan finns omvandlas problemet att lärarna saknar en egen vetenskap till att bli en fråga om att lärare inte använder den kunskap som finns. Artikeln beskriver några aspekter av pedagogikens utveckling - på universitetet såväl som på lärarutbildningen - med fokus på relationen mellan pedagogiken och lärarna. Avslutningsvis diskuteras inrättandet av utbildningsvetenskap och de möjligheter att tydligare urskilja olika pedagogiska kunskapsområden och därigenom realistiska förväntningar på vad dessa olika områden kan eller inte kan bidra med till läraryrket och lärarutbildningen.

\section{INTRODUKTION}

I början av 1970-talet blev jag klar med min psykologexamen, vilket på den tiden innebar att jag gått ganska många kurser på pedagogiska institutionen. 
Många av oss som blev psykologer skrev också våra uppsatser på pedagogiska institutionen och en del blev kvar där som lärare och forskare. De blivande lärarna gick på lärarutbildningarna, som levde sina egna liv i stort sett utan kontakt med de pedagogiska universitetsinstitutionerna. Ett undantag utgjordes av vårdlärarutbildningen där lärare från pedagogiska institutionen undervisade. För att få lov att undervisa på andra lärarutbildningar krävdes en lärarexamen vilket inte var vanligt bland universitetspedagoger. Dock fanns möjlighet för lärare att under ett år studera med så kallat B-avdrag på lönen, vilket under 1970-talet utnyttjades av många lärare för att läsa universitetets grundkurser i pedagogik.

Själv blev jag skolpsykolog och det var som sådan jag mötte lärare på alla skolstadier från lågstadiet till gymnasiet. På lågstadiet ägnade vi psykologer mycket tid åt att utreda barn som skulle placeras i särskilda klasser, till exempel hjälpklass eller obsklass. Som elevvårdare samarbetade vi nära med rektorerna och ofta för att i olika projekt få lärarna att förändra sina arbetssätt. Det var under den tiden som mitt intresse för pedagogiken och lärarna tog form. Det var uppenbart att pedagogiken inte var lärarnas vetenskap. Inom pedagogiken framställdes ofta lärarna som problemet i skolan - de sågs ofta som bromsklossar och bakåtsträvare i reformeringen av skolan. Med mina pedagogiska och psykologiska glasögon betedde de sig ofta helt fel - och konstigt nog tycktes de själva acceptera bilden av det de höll på med som något alldeles felaktigt. ${ }^{1}$ När jag senare började forskarutbildningen i pedagogik (genom att bli studerande gick det nämligen att få dagisplatser till barnen) visade det sig dock att de frågor och problem som tagit form i mötet med skolan inte riktigt platsade $i$ det pedagogiska forskningsfältet. Erfarenheter från skolan uppfattades varken som meriterande eller önskvärda.

Kännedomen om att pedagogiken på lärarutbildningarna och på de universitetspedagogiska institutionerna inte hänger ihop utan närmast utgör två skilda världar, finns oftast inte utanför pedagogiken - och sannolikt inte heller bland lärare. På de pedagogiska institutionerna finns forskningsresurser och det är där som den pedagogiska forskningen i stor utsträckning bedrivs. Pedagogiken på lärarutbildningen, som till största delen saknar egna forskningstraditioner, förväntas ge en teoretisk grund för undervisningsmetoder och arbetssätt i överensstämmelse med skolans läroplaner. Eftersom den pedagogiska forskningen sällan handlar om frågor och problem som lärare ställs inför, importeras istället de teoretiska perspektiv som omgärdar den pedagogiska forskningen. Dessa perspektiv får på lärarutbildningen en normativ funktion som en "teoretisk" grund för de metoder och arbetssätt som uppfattas som önskvärda. På så vis har vissa teoretiska perspektiv förknippats med god undervisning. Vissa sätt att organisera undervisningen uppfattas vara "konstruktivistiska" eller "sociokulturella". Istället för att fungera som analytiska redskap förvandlas de 
teoretiska perspektiven till ideologi för den goda undervisningen. Denna skillnad mellan hur exempelvis konstruktivistiska perspektiv används i den pedagogiska forskningen och på lärarutbildningen uppmärksammas inte i den debatt där så kallad konstruktivistisk undervisning kritiseras. Istället anklagas pedagogiken $\mathrm{i}$ en vag och allmän betydelse. Förutom att ämnesföreträdarna på de pedagogiska institutionerna känner sig kritiserade för saker som de inte känner igen, skapar denna brist på åtskillnad mellan pedagogisk forskning och lärarutbildning förvirring som vare sig gagnar pedagogiken eller lärarna.

Sammantaget har vi en situation där "pedagogiken" kan syfta på undervisningens uppläggning, ett innehåll i lärarutbildningen eller på en universitetsdisciplin. Och "pedagoger" kan vara förskollärare, skolbyråkrater, lärarutbildare eller forskare. Eftersom skola, lärarutbildning, skolmyndigheter och pedagogiska institutioner är skilda världar i stort sett utan interaktion blir kritik som riktas mot "pedagogik" eller "pedagoger" utan en tydlig mottagare. Det är kanske en av anledningarna till att "pedagogerna" tiger, vilket Magnus Henrekson klagade på i en gästkrönika i Göteborgsposten (Skogstad, 2018, $7 / 1)^{2}$

Det är mot bakgrund av den ovan beskrivna situationen som jag vill ägna mitt bidrag till det här specialnumret om pedagogikfältet till att bena ut några oklarheter. Jag ska försöka beskriva hur pedagogiken utvecklats från att ha inrättats som en vetenskap för lärare och lärarutbildning till att istället bli en vetenskap för utbildningspolitiken; till en början genom bidrag till konstruktionen av skolreformer men efterhand alltmer som kritik av såväl den existerande skolverksamheterna som av reformsträvanden. Jag ska också försöka beskriva hur den pedagogik som förmedlas på lärarutbildningarna är något annat än på de pedagogiska institutionerna. Mitt syfte är också att visa hur situationen/oklarheterna inte endast skapar missförstånd, utan också hindrar läraryrkets professionalisering genom att bromsa utvecklingen av en för läraryrket specifik kunskapsbas. En viktig utgångspunkt för mina resonemang är att pedagogik, i likhet med flera andra discipliner, kan tillföra lärarutbildningen kunskaper som fördjupar de blivande lärarnas förståelse för skolan, läroplanerna och styrsystemet liksom för elevernas utveckling och lärande $\mathrm{i}$ allmänhet. Men dessa kunskaper är inte tillräckliga som redskap i själva yrkesutövandet. Detta handlar i mycket stor utsträckning om att skapa förutsättningar för elever att nå alla de konkreta lärandemål som finns inom skolans olika ämnen - som att utveckla elevernas förståelse för likhetstecknet i den grundläggande matematikundervisningen.

För att undvika förvirring i debatten såväl som orealistiska förväntningar på pedagogiken tror jag att vi behöver en mer differentierad begreppsapparat för att tala om det pedagogiska kunskapsområdet. Genom etableringen av utbildningsvetenskap har vi fått förutsättningar att tydligare specificera olika inriktningar och därigenom kan det också tydliggöras vilka slags kunskaper 
som olika delar av fältet ägnar sig åt och på vilka sätt de kan eller inte kan komma lärarna till godo.

\section{FRÅN PEDAGOGIK FÖR LÄRARE TILL EN PEDAGOGIK LÅNGT BORTA}

\section{FRÅN LÄRARNA}

I sin avhandling Kampen om katedern (Florin 1987) beskriver Christina Florin hur folkskollärarnas professionaliseringskamp bland annat resulterade i en förlängning av utbildningen och etablerandet av pedagogik som vetenskaplig disciplin i Sverige. Den första professuren i pedagogik knöts till lärarutbildningen. ${ }^{3}$ Det var under en period då folkskollärarna agerade på olika arenor för utvecklingen av skolan. De hördes i det offentliga samtalet, några blev folkskoleinspektörer och en blev minister (Fridtjuv Berg). Vart femte år samlades flera tusen lärare från hela Norden till föreläsningar, seminarier och diskussioner om skolfrågor på de Nordiska skolmötena, där också skolpolitiker och forskare deltog (Landahl, 2015). Många folkskollärare var aktiva förespråkare för olika reformpedagogiska strävanden. En av de mer framträdande var Esther Hermansson (1974) som i sina memoarer beskriver hur lärarna aktivt medverkade i utvecklingen av de pedagogiska verksamheterna från början till mitten av 1900-talet. Tillsammans med en kollega åkte hon på 1930-talet till USA för att lära sig mer om den pedagogiska progressivismen. På 1940-talet deltog hon med några andra lärarinnor i Skolkommissionens arbete med enhetsskolereformen.

\section{Pedagogiken och skolreformerna}

Efter andra världskriget hamnade avskaffandet av parallellskolesystemet högt på dagordningen. Detta bidrog i sin tur till pedagogikämnets återkomst som självständig disciplin. ${ }^{4}$

Reformeringen av skolan reste en rad frågor - framförallt frågor om differentiering (till den diskussionen bidrog inte minst Torsten Husén (1948) och Kjell Härnqvist (1958) med sina analyser av begåvningsreserven i olika sociala grupper) och behovet av en pedagogik för alltmer heterogena klasser. Forskningen knöts till frågor om utbildningssystemets organisering och innehåll snarare än till att utveckla kunskaper till grund för lärarnas professionsutövning.

Den nära koppling som under 1900-talets första decennier fanns mellan pedagogik/pedagogisk forskning och lärarna upphörde i samband med planeringen och förberedelserna för de stora skolreformerna. Hermansson skriver om frustrationen över att fortbildningsaktiviteter och andra insatser flyttades från att drivas av lärare till andra aktörer. Trots att folkskollärarna länge varit drivande $i$ den så kallade bottenskolefrågan (dvs. en gemensam grundskola för alla barn) och haft representanter i 1946 års Skolkommission innebar den reformperiod som inleddes med Riksdagsbeslutet 1950 en 
successiv marginalisering av lärarna, och samtidigt ett ökande inflytande för universitetspedagogiken (Carlgren, 1986). Universitetspedagogerna identifierade sig starkt med skolreformerna vilket bland annat uppmärksammats $i$ den utvärdering av pedagogikämnet som HSFR gjorde. Den internationella expertpanelen pekade där ut vad de beskrev som en järntriangel bestående av pedagogiska forskare, politiker och centralbyråkrater (Rosengren \& Öhngren, 1997)

Under tiden efter 1950 expanderade den statliga skolmyndigheten (Skolöverstyrelsen) kraftigt och forskningen skildes från den nära kontakten med lärarna. $1950 \mathrm{skrev}$ dåvarande ecklesiastikministern att lärarna nu inte längre behövde så mycket teori och forskning som konkreta anvisningar för sitt arbete (Carlgren, 1986). Ur ett professionaliseringsperspektiv innebar det att lärarna förlorade kontrollen över kunskapsutvecklingen i yrket. Det var nu universitetspedagogerna som hade facit för hur arbetet i skolan borde vara.

\section{Den kritiska pedagogiken och lärarna}

Inom pedagogikdisciplinen fick den vetenskapsteoretiska diskussion som följde i spåren av Thomas Kuhns The structure of scientific revolutions (1962) stort genomslag tillsammans med en allmän positivismkritik och framhävande av hermeneutiska och kritiska forskningsansatser (se t.ex. Lesche, 1972; Ödman, 1979). Kritiken riktades bland annat mot den forskning som tagit till uppgift att tillhandahålla instrument och råd inför olika aspekter av skolreformerna. Denna kritiska pedagogik vilade ofta på strukturalistiska teorier där konfliktoch maktperspektiv var centrala. Skolans repressiva funktion betonades (se t.ex. Callewaert \& Nilsson, 1977). Detta ökade ytterligare klyftan till lärarna eftersom de ju framstod som maktens viktigaste redskap. Detta blev särskilt tydligt i teorierna om den dolda läroplanen (Broady, 1985), som fick stor spridning också på lärarutbildningarna. I likhet med annan pedagogisk forskning anpassades dock teorin om den dolda läroplanen till det normativa lärarutbildningsparadigmet så att den kunde användas som beskrivning av traditionell undervisning och därmed det icke önskvärda, till skillnad från de undervisningsformer som förordades på lärarutbildningen. Som om progressiv pedagogik inte skulle ha någon dold läroplan.

Efterhand har de strukturalistiska teorierna ersatts av poststrukturalistiska och postkoloniala teorier. Med Foucault och postmodernismen uppmärksammades alltmer den "mjuka makten" och hur olika former av självreglerande mekanismer iscensätts i skolan (t.ex. Popkewitz, 1997) ${ }^{5}$. Utvecklingen inom pedagogiken speglar på så vis utvecklingen inom samhällsvetenskapen i stort. Till skillnad från 1970- och 80-talens strävan efter att utveckla pedagogik som en självständig samhällsvetenskaplig disciplin med egen teoriutveckling (där ramfaktorteorin var central) verkar pedagogikämnet alltmer har kommit att bli ett tillämpningsområde för andra samhällsvetenskapliga discipliner och filosofi. 
Med den kritiska pedagogiken hamnade inte endast lärarna utan också reformmakarnas strävanden $i$ fokus för kritiken. Inriktningen mot dekonstruktion snarare än konstruktion tillsammans med en motvilja mot instrumentalism och tekniska frågor har skapat en disciplin som inte tycks vilja vara nyttig för någon. Det kan vara värt att fundera över om inte pedagogiken dragit undan mattan under fötterna på sig själv genom denna förflyttning från att vilja medverka till konstruktionen av nya skolsystem till att istället dekonstruera alla de texter som systemet producerar. Frågan är hur en pedagogik utan förankring vare sig i lärarutbildningen eller reformmakandet kan överleva. Sannolikt krävs en betydligt starkare egen teoriutveckling i linje med den strävan som fanns på 1970- och 80-talen (Dahllöf, 1989).

\section{PEDAGOGIKEN OCH LÄRARUTBILDNINGEN}

Frågan om lärarutbildningens vetenskapliga och teoretiska grund har länge varit en omtvistad fråga. I betänkandet Den första Lärarbögskolan (SOU 1952:33) föreslogs psykologi som grundläggande ämne i lärarutbildningen. På 1960-talet föreslogs istället pedagogik (SOU 1965:29) medan 1970-talets lärarutbildningsutredning (SOU 1978:86) föreslog didaktik som kärnämne i lärarutbildningen. Trots att pedagogik alltså inte på länge haft ett tydligt utrymme i lärarutbildningen verkar uppfattningen att det är på det viset vara spridd.

Även om lärarutbildningens behov var ett av motiven till inrättandet av den första pedagogikprofessuren har inte pedagogiken utvecklats på eller i samverkan med lärarutbildningen. Visserligen inrättades på 1960-talet flera professurer i praktisk pedagogik på de nyinrättade lärarhögskolorna, men detta tycks framförallt ha inneburit upprättande av pedagogiska forskningsmiljöer på samma plats som lärarutbildningarna - men utan direkt kontakt med dessa. ${ }^{6}$

Efter 1977 har pressen på lärarutbildningen att bli mer akademisk funnits. En följd av det är en inriktning mot att anställa disputerade lärare. Eftersom forskningstraditioner saknas i lärarutbildningen har det skapat en situation där akademiskt meriterade lärare (som doktorerat inom ett undervisningsämne eller i pedagogik) dessvärre ofta inte haft vare sig erfarenhet av skolan eller intresse för lärares frågor och istället tagit med sig de forskningstraditioner de disputerat inom. En annan aspekt är att många lärarutbildare sökt sig till forskarutbildningen i pedagogik. Där har en vanlig uppfattning varit att forskning är ett särskilt yrke och att lärare som ska forska måste hänga av sig lärarkappan. På det viset har forskarutbildningen i pedagogik snarare fungerat som en omskolningskurs för lärarutbildarna, som efter disputationen inte vill tillbaka till undervisningen utan istället ägna sig åt de frågor som universitetspedagogiken prioriterar. Det är stora satsningar som gjorts för att 
forskarutbilda lärarutbildare utan att de pedagogiska institutionernas forskarutbildningar anpassats och utan att nyttan av detta för lärarutbildningen problematiserats.

Den ämnesdidaktika forskningen, som på flera lärarutbildningar tog fart under 1990-talet, har varit mer direkt inriktad mot lärarprofessionens frågor. Dock utvecklades den inte utifrån de kunskaper som utvecklats vid lärarutbildningarnas metodikinstitutioner utan sågs snarare som ett vetenskapligt alternativ till metodiken, som kritiserades för att vara uppbyggd kring metodiska tips. På så vis kom den mer konkret inriktade metodiken att på flera håll ersättas av didaktikens teoretiska perspektiv som i stor utsträckning importerats från pedagogik och andra samhällsvetenskapliga discipliner. Med tanke på att det främst var på metodikinstitutionerna som professionens kunskap fanns lagrad har deras försvinnande sannolikt bidragit till den professionella kunskapsbasens försvagning.

Ända sedan lärarutbildningarna integrerades i högskolesystemet 1977 har det funnits en motsättning mellan kraven att akademisera och kraven på ändamålsenlighet i förhållande till yrket. Frågan om knytningen mellan teori och praktik har därför blivit central - oftast med utgångspunkten att det är teorin som är det rätta medan praktiken är fel och behöver rättas till. Detta synsätt kan spåras ända tillbaka till inrättandet av lärarseminarierna på 1800talet. Deras uppgift var att utbilda de blivande lärarna till att bedriva en verksamhet som var något annat än den som bedrevs i skolan. Utbildningarna utbildade i nya metoder och arbetssätt. Det första seminariet i Stockholm av Växelundervisningens vänner inrättades till exempel $\mathrm{i}$ syfte att föra ut växelundervisningens metodik. Detta inbyggda missionsmotiv i lärarutbildningarna har ibland gjort det svårt att låta erfarna lärare i skolorna få rollen som mästare och förebilder. Dessa uppfattades ju representera den traditionella undervisningen, vilken ju ansågs borde ersättas av nya metoder och arbetssätt. På lärarutbildningarna förmedlades visioner om vad skolan skulle kunna vara och bur undervisning borde bedrivas. Inom lärarutbildningsforskningen finns beskrivet hur lärarstudenterna under sin utbildningstid tillägnar sig dessa visioner liksom hur de, när de möter verklighetens klassrum, får en "praktikchock" och därefter i allmänhet glömmer vad de lärt sig på utbildningen när de försöker överleva i klassrummet (Carlgren, 1996; Jordell, 1986).

Men det har också funnits strävanden att få till stånd en mer lärarutbildningsanpassad pedagogisk forskning. På 1990-talet etablerades ämnet pedagogiskt arbete på ett par ställen (bl.a. Umeå och Linköping). Det var ett sätt att markera knytningen till en verksamhet snarare än till en disciplin. I Umeå förenades det med inrättandet av en fakultet för lärarutbildningen. Tanken var att - $\mathrm{i}$ analogi med medicinarutbildningarna - inte låta disciplinlogiken bestämma progressionen $\mathrm{i}$ lärares utbildning. Olika medicinska examina (som t.ex. med.kand och med. Dr.) är inte bundna till en 
progression inom discipliner så som är fallet inom den filosofiska fakultetens ämnen.

På andra håll skapades istället nya ämnen. I Luleå och Norrköping inrättades lärande som ett huvudämne i lärarutbildningen och i Malmö gjordes försök att organisera utbildningen $i$ relation till ett antal så kallade sakområden som senare utvecklades till huvudämnen där ämnesstudierna integrerades med didaktiken. ${ }^{7}$ På motsvarande sätt byggdes lärarutbildningen i Norrköping upp runt skolämnen, där ämnesstudierna organiserades på ett lärarutbildningsanpassat sätt samtidigt som didaktiska, vetenskapsteoretiska och idéhistoriska perspektiv integrerades.

Till skillnad från sjuksköterskeutbildningarna, som 1977 kom in i högskolesystemet samtidigt med lärarutbildningarna, har inte lärarutbildningarna lyckats etablera ett stabilt huvudämne eller kunskapsområde som formar lärarnas yrkesidentitet och vars innehåll bidrar till kvaliteten i yrkesutövandet; ett ämne inom vilket fördjupade studier leder till såväl högre akademiska examina som mer kvalificerade yrkesuppgifter. Istället erbjuder den så kallade utbildningsvetenskapliga kärnan ett smörgåsbord av olika kurser. Den lägger inte heller en grund för fördjupade studier och kvalificering i yrket. Skolkommissionens förslag (SOU 2017:35) om att bygga ett professionsprogram vid sidan av lärarutbildningarna är en bekräftelse på detta.

Tydligast när det gäller att försöka få till stånd en för läraryrket unik kunskapsbas är dock de ämnesdidaktiska miljöer som utvecklats på vissa håll och inom vissa ämnesområden. Dessvärre innebar lärarutbildningsreformen 2011 (SOU 2008:109) ett bakslag för ämnesdidaktiken genom att den utbildningsvetenskapliga kärnan gavs ett stort utrymme. ${ }^{8}$ Efter ett par decennier av utbyggnad av ämnesdidaktiken - i utbildningen såväl som $\mathrm{i}$ forskningen - innebar reformen 2011 ett återtagande av utrymme för såväl ämnesstudier som för pedagogik. För grundlärarnas del innebar det en återgång till en situation där möjlighet till ämnesdidaktisk fördjupning och forskarutbildning stängdes. Återigen är pedagogik den väg till doktorsexamen som framförallt erbjuds dessa lärare.

\section{SKOLUTVECKLINGEN, FORSKNINGEN OCH LÄRARNA}

Den pedagogiska forskningens roll för skolutveckling och för lärares arbete har skiftat. Ibland har den genererat kunskaper som lärare kan använda, men oftare kunskaper som kan användas av beslutsfattare och utbildningsansvariga. Den kritiska pedagogiken genererar inte kunskaper som direkt kan användas men bidrar till att belysa olika slags problem i systemet och i verksamheten. Det märkliga är, att parallellt med att intresset för undervisningsfrågor inom den pedagogiska forskningen minskade till förmån för utbildningsfrågor marginaliserades lärarna när det gällde inflytande över 
fortbildning och skolutveckling. Den kontakt som skulle finnas mellan lärarna och forskningen i den av 1946 års Skolkommission (SOU 1948:27) föreslagna så kallade särskilda försöksverksambeten (där lärarna skulle formulera hypoteser för forskarna att pröva) på 1950-talet och också i de så kallade pedagogiska utvecklingsblocken (på 1960-talet) där lärarna förväntades hitta praktiskt framkomliga vägar för olika beslut i reformerna som skulle utvärderas av forskarna försvann i samband med framväxten av det som kallades lokalt utvecklingsarbete på 1970-talet. Medan försöksverksamheten på 1940- och 50talen syftade till att producera ny kunskap syftade de pedagogiska utvecklingsblocken att hitta praktiskt framkomliga vägar för att genomföra beslutade reformer. I kontrast till det var det lokala utvecklingsarbetet på 1970- och 80-talen ett lärardrivet utvecklingsarbete som syftade till att omsätta forskningens resultat i klassrummet (Carlgren, 1986; Carlgren \& Hörnqvist, 1999). Detta alltså samtidigt som stora delar av den pedagogiska forskningen bytte inriktning och ägnade sig åt andra frågor än de lärarna arbetade med. Istället blev lärarnas uppgift att omsätta forskningens resultat ett studieobjekt i den pedagogiska forskningen.

Den sammantagna effekten blev att lärarnas roll förändrades från att vara subjekt $i$ forskningen till att bli objekt för forskningen. Antagandet att det fanns forskningsresultat att omsätta i klassrummet ifrågasattes inte ${ }^{9}$, däremot lärarnas ovilja $\mathrm{i}$ reformarbetet. Den motvilja som många gånger fanns bland lärare mot olika reformer uppfattades som ett stort hinder för skolutveckling. Reformerna som sådana ifrågasattes inte utan istället uppfattades lärarna som problemet (ett tydligt exempel på det är Sandström \& Ekholm, 1984).

Olika modeller för att få lärare att i grupp hjälpa varandra att förändra sina arbetssätt utvecklades..$^{10}$ Medan forskningen knöts till frågor om reformer och reformimplementering knöts förändringen av skolans arbetssätt till fortbildning av lärare. 1980 manifesterades utvecklingen i Skolforskningskommitténs förslag (SOU 1980:2) att forskningen skulle knytas till den långsiktiga utbildningsplaneringen medan utvecklingsarbetet $\mathrm{i}$ skolan skulle åstadkommas genom fortbildning. Lärarna uppfattades behöva fortbildning och kompetensutveckling snarare än en forskningsbaserad kunskapsutveckling där de själva medverkar. Genom fortbildning skulle de få redskap att förändra skolpraktiken - underförstått att en sådan kunskap och sådana redskap fanns. ${ }^{11}$ Det var pedagogiken som hade tolkningsföreträde.

Under slutet av 1990-talet inrättades ett par nationella forskarskolor (en i naturvetenskapens och teknikens didaktik och en i pedagogiskt arbete). Därefter har olika satsningar på forskarskolor med inriktning mot lic-examen för lärare gjorts. Idén om behovet av en praktiknära forskning lanserades i en departementsrapport i mitten av 1990-talet (Ds 1996:16). 1999 föreslog Lärarutbildningskommittén (SOU 1999:63) inrättandet av utbildningsvetenskap som vetenskapsområde. Tanken var att det därigenom skulle öppnas möjligheter att fördela basanslag för forskning och 
forskarutbildning också till lärarutbildningarna. Reaktionen mot förslaget blev dock alltför kraftig (inte minst från de traditionella lärosätena), varför förslaget istället omvandlades till att inrätta en utbildningsvetenskaplig kommitté (UVK) inom ramen för det nybildade Vetenskapsrådet. Detta fick till följd att de medel som var tänkta att främja uppbyggnaden av forskningstraditioner inom lärarutbildningen istället kom att användas till att fördela forskningsmedel till olika projekt vid de forskningsmiljöer som redan fanns utanför lärarutbildningen. För att vara ett forskningsråd fick UVK ganska mycket pengar vilket fått som konsekvens att den utbildningsvetenskapliga forskningen expanderat och $\mathrm{i}$ allt högre utsträckning bedrivs utanför pedagogiken. Dock hade UVK ett särskilt uppdrag att främja utvecklingen av forskning av relevans för skola och lärarutbildning vilket bland annat ledde till en satsning på vad som då kallades praxisnära forskning (Carlgren, Josefson \& Liberg, 2005). I samband med byte av huvudsekreterare och att pedagogiken fick ett större inflytande över UVK ${ }^{12}$ avvecklades dock satsningen på praxisnära forskning. Än en gång visade sig företrädare för den pedagogiska disciplinen ha liten förståelse för lärarnas forskningsbehov. ${ }^{13}$

Denna utveckling föranledde bland andra lärarförbunden och SKL (Sveriges kommuner och landsting) att driva frågan om ett Skolforskningsinstitut, som så småningom kom att inrättas (2015). Dock var det långt ifrån självklart att detta institut skulle fördela forskningspengar. Istället var tanken att institutet, $i$ likhet med många så kallade clearing houses $i$ andra länder, skulle fungera som "mäklare" av forskning, det vill säga arbeta med forskningssammanställningar och spridning av dessa till skolfältet. Till sist inkluderades ändå förslaget om att också fördela resurser till praktiknära forskning för att stärka forskningssvaga områden. Dessa resurser blev dock (särskilt i jämförelse med UVK) närmast löjligt små.

Sammantaget har vi en situation där idén om läraryrket som en profession som, i interaktion med en egen forskningsgrundad kunskapsbas, driver utvecklingen av de pedagogiska verksamheterna verkar ha svårt att få fäste. Lärarna som objekt för olika slags åtgärder är en seg tankefigur. När lärarkåren får nya uppgifter eller nya problem uppstår ropas det efter fortbildning. Som om det finns någon som har svaret. Som om det inte behövs ett FoU-arbete i skolan för att utveckla verksamheten. Till och med i forskningsprojekt där lärare och forskare samverkar beskrivs resultaten ofta i termer av vad lärarna lärde sig - inte i termer av den kunskap som utvecklades (och inte heller i termer av vad forskarna lärde sig). Också i den försöksverksamhet som flera lärosäten initierat för att utveckla den praktiknära forskningen (det s.k. ULFprojektet) är det mer eller mindre underförstått att praktiknära forskning huvudsakligen handlar om att föra ut universitetens forskning till praktiken inte att generera ny kunskap. Detta tankemönster verkar vara paradigmatiskt. Därför omvandlas hela tiden olika idéer om en praktikgrundad kunskapsutveckling för lärarprofessionen i linje med ett sådant paradigm, det 
vill säga utifrån föreställningen att den kunskap lärare behöver redan utvecklats av andra någon annanstans - och att den praktiknära forskningen därför handlar om att lärare ska omsätta denna forskning i klassrummen genom olika former av kollegial samverkan.

I utredningen om praktiknära forskning i samverkan (SOU 2018:19) visar det sig att merparten av de miljöer för samverkan akademi skola som finns runt om i landet handlar om fortbildning och kompetensutveckling. Några enstaka exempel på regionala/kommunala organisationer för att främja praktiknära forskning där lärare medverkar i produktionen av ny kunskap finns dock.

\section{ÄR PEDAGOGIKEN ETT HINDER FÖR LÄRARPROFESSIONENS UTVECKLING?}

Pedagogikdisciplinen är idag inte lärarnas vetenskap fast det var med den ambitionen det en gång började. Detta skulle inte behöva vara något större problem, men blir det genom att en så stor del av skoldiskussionen bygger på att det är så. För pedagogikens del skapas därmed orealistiska förväntningar och för läraryrkets del motverkas yrkets professionalisering. Istället för att låta lärarprofessionen vara drivande när det gäller undervisningens utveckling hanteras lärarna som en betingelse för skolans utveckling. Ett exempel på det är det genomslag som Hatties metastudier fått (Hattie, 2008). Dessa bygger på studier av lärare, undervisning och elevers resultat. Ett av de mest kända resultaten är att lärarna utgör en av de faktorer [sic!] som har störst betydelse för elevernas framgångar. Sådana föga förvånande resultat används idag för att ge utbildningen en vetenskaplig grund. Genom att satsa på kompetensutveckling av lärarna, gärna genom kollegial samverkan, tillämpas det som forskningen visat, nämligen att mer kvalificerade lärare får bättre resultat. ${ }^{14}$ Utveckling av undervisning uppfattas alltså inte i första hand som en fråga om forskning och kunskapsutveckling, utan istället som en fråga om fortbildning och kompetensutveckling. Lärarna hanteras fortsatt som objekt.

Lärarprofessionen behöver ett eget kunskapsområde att knyta kunskapsutvecklingen till. Den utbildningsvetenskapliga kärna som infördes 2011 är mer av ett smörgåsbord av olika kunskaper som kan vara bra för lärare att ha. Den fungerar varken som en grund att bygga vidare på eller som ett ämnesområde att organisera yrkeskunnandet kring. Eftersom lärares arbete handlar om kunskaper, kunnande, lärande och undervisning inom olika ämnen ${ }^{15}$ ligger det nära till hands att se (ämnes)didaktik som utbildningens huvudämne och att det som behöver utvecklas är ämnesdidaktiska forskarutbildningar samt inrättande av ämnesdidaktiska professurer. Till stor del är det en resursfråga. Idag är det ämnesinstitutioner och pedagogiska institutioner som har forskningsresurserna. 
Dagens krav på att all utbildning ska vila på vetenskaplig grund innebär att det är den forskning som finns som används - oavsett relevans. Den pedagogiska forskning som i stor utsträckning handlat om lärare förväntas nu användas av lärare. Problemen med att utveckla en vetenskap för lärare är fortsatt stora. ${ }^{16}$ Till detta bidrar också att kraven på akademisering har lett till att lärarutbildningen har rekryterat disputerade lärare som inte själva är lärare eller har erfarenhet från skolan. Deras forskningsintressen sammanfaller därför ofta inte med lärarutbildningens behov. Detta i kombination med att pedagogiska forskarutbildningar ligger vid sidan av lärarutbildningen kommer inte att bidra till att utveckla en för lärarutbildningen egen kunskapsbas. Till detta bidrar också lärarutbildningens tradition att förvandla teoretiska perspektiv till ideologi och instruktion för undervisning.

\section{VÄGEN FRAMÅT}

För det första måste frågan om lärarutbildningarnas basanslag för forskning och forskarutbildning lösas, vilket bland annat innebär en omfördelning av resurser. Sannolikt har pedagogikämnet fortfarande för stora forskningsresurser i förhållande till lärarutbildningarna. Ett exempel på hur en sådan omfördelning kan gå till prövades på Lärarhögskolan i Stockholm i början av 00-talet. Då delades upp pedagogikämnet i fyra ämnen med egna forskarutbildningar: pedagogik, didaktik, specialpedagogik samt barn- och ungdomsvetenskap. Vi som var professorer i pedagogik fick välja vilket ämne vi skulle tillhöra. Det blev därigenom möjligt att knyta barn- och ungdomsvetenskapen till förskollärarutbildningen, didaktiken till lärarprogrammen och specialpedagogiken till utbildningen av speciallärare och specialpedagoger.

Frågan är om inte pedagogik som en samhällsvetenskaplig disciplin har spelat ut sin roll. Som eget ämne är pedagogik numera nedlagt vid ett par lärosäten (bl.a. Lund och Karlstad). På andra lärosäten ingår pedagogikämnet i större institutionsbildningar. Internationellt har det inte funnits motsvarande pedagogiska discipliner. Med etableringen av utbildningsvetenskap har fältet breddats samtidigt som behovet av att specificera olika inriktningar vuxit. Innan utbildningsvetenskapliga kommittén bildades sökte pedagogiska forskare projektmedel från dåvarande HSFR (Det humanistiska och samhällsvetenskapliga forskningsrådet). Inför bildandet av UVK fördes diskussioner inom HSFR:s pedagogiska beredningsgrupp om att pedagogikdisciplinen fortsatt skulle tillhöra den samhällsvetenskapliga familjen och HS-området, medan utbildningsvetenskap snarare skulle ses som ett mångvetenskapligt verksamhetsområde. Resurserna inom UVK blev dock ganska omfattande i relation till de resurser som pedagogiken kunde göra anspråk på inom HS-området, varför de pedagogiska forskarna istället sökte 
sig dit. Kanske går det att hävda att pedagogiken därigenom (omedvetet) lämnade sin samhällsvetenskapliga tillhörighet.

Jag tror att vägen framåt handlar om att se utbildningsvetenskap som ett brett forskningsområde men också som ett professionsinriktat fakultetsområde. För lärarprofessionens utveckling skulle det öppna för att skapa akademiska progressionsvägar som inte är disciplingrundade. Utbildningsvetenskapens olika kunskapsområden och forskningsinriktningar skulle dock göras tydligare än idag; didaktik, lärandeforskning, kognitionsforskning, läroplansteori, utbildningssociologi, utbildningshistoria, organisation och ledning, utbildningspolitik, utbildningsfilosofi etcetera. En sådan utveckling skulle göra lärarutbildningen mer lik andra stora professionsutbildningar (t.ex. tekniska och medicinska) och mer lik den internationella situationen. Det skulle också möjliggöra utvecklingen av (ämnes)didaktik som lärarprofessionens kunskapsbas med fokus på undervisning, lärande och kunnande inom olika ämnesområden och åldersgrupper. En förutsättning är att den ämnesdidaktiska forskningen inte försvinner in i samhällsvetenskapen utan utvecklas i samspel med såväl ämnesinstitutioner som den pedagogiska praktiken och lärares didaktiska arbete. Endast så kan fördjupade studier (och högre examina) också leda till mer kvalificerade yrkesutövare.

\footnotetext{
NOTER

${ }^{1}$ När jag tillsammans med Bo Dahlin i ett projekt om "Lärares arbete" i mitten av 1980-talet intervjuade lärare på grundskolan om deras arbete, visade det sig att de helst inte ville prata om det de faktiskt gjorde utan istället om vad de menade att de borde göra. Deras språk för att tala om pedagogiska ideal var mycket mer utvecklat än språket för att tala om realiteterna i arbetet.

${ }^{2}$ En annan är att pedagoger inte släpps in i tidningarna genom att artiklar som skrivs av pedagoger refuseras.

${ }^{3}$ Bertil Hammer, 1910.

${ }^{4}$ Efter den första professuren i pedagogik uppgick pedagogiken i psykologin och återkom inte som självständig disciplin förrän i slutet av 1940-talet.

5 Thomas Popkewitz' inflytande på den svenska pedagogiska forskningen ska inte underskattas. Dels har han genom olika stipendier arbetat under perioder i såväl Sverige som Finland, dels har han varit knuten som expert till flera lärosäten och stora forskningsprojekt.

${ }^{6}$ I Uppsala placerades den nytillträdde professorn i praktisk pedagogik, Karl-Georg Ahlström, dessutom en bra bit bort från lärarutbildingsbyggnaden.

${ }^{7}$ Lärarutbildningen vid Malmö högskola har en särskild profil genom våra huvudämnen där ämneskunskaper kombineras med hur man gör ämnet begripligt i klassrummet. I huvudämnet integreras även frågor som är angelägna för alla lärare såsom barns och ungdomars utveckling och lärande, samhällsuppdraget,
} 
värdegrunds- och demokratifrågor, undervisning och kulturfrågor. Inom de olika huvudämnena studeras också grupprocesser och konflikthantering samt bedömningsfrågor.

8 Vilket, paradoxalt nog, innebar att det gemensamma innehållet i de olika lärarprogrammen ökade trots att ett av motiven bakom reformen var att minska de gemensamma delarna av lärarutbildningen.

${ }^{9}$ Trots att det saknas evidens för att vissa arbetsformer är generellt sett bättre än andra har hela tiden skolutvecklingsdiskursen förutsatt att de arbetsformer och arbetssätt som förordas också är forskningsgrundade.

10 T.ex. personallagsutbildningen (PLAG) som kan ses som en föregångare till dagens kollegiala lärande.

11 Riksdagsbeslutet om enhetsskolan 1950 var förbundet med en 10-årig försöksverksamhet där såväl effekter av organisation och arbetsformer skulle prövas. I uppföljningen av försöksverksamheten konstaterade författarna att resultaten när det gällde nya arbetssätt och arbetsformer inte var så tydliga. Detta påverkade dock inte retoriken omkring de nya arbetssätt och arbetsformer som skulle införas.

12 Ulf P. Lundgren blev huvudsekreterare, Elisabeth Nihlfors bitr. huvudsekreterare och Sigbrit Franke ordförande.

${ }^{13}$ Dock fanns forskare med intresse för att driva fram en mer lärarrelevant forskning. Flera av dessa var knutna till Lärarförbundets vetenskapliga råd, som aktivt drev bl.a. frågan om att minst en promille av kommunernas skolbudgetar borde gå till forsknings- och utvecklingsarbete i skolan. I t.ex. Stockholm ledde detta till inrättandet av en kommunalt finansierad forskarskola i ämnesdidaktik och till utvecklingen av plattformen Stockholm Teaching and Learning Studies.

${ }^{14}$ Genom att framställa sådana snusförnuftigheter (som att lärares kompetens har betydelse för resultaten) som skolans vetenskapliga grund tas fokus från alla de frågor och problem som uppstår i undervisningen och som lärarna skulle behöva forskningsgrundade kunskaper för att lösa.

${ }^{15}$ Detta gäller också om man är lärare för yngre åldrar. Också språk- och talutveckling är innehållsliga till sin karaktär.

${ }^{16}$ En jämförelse med det medicinska området är slående. Medan ca $80 \%$ av den medicinska forskningen är s.k. klinisk forskning (dvs. forskning $\mathrm{i}$ anslutning till vårdprofessionernas frågor och problem) är situationen inom utbildningsområdet snarare det omvända.

\section{REFERENSER}

Broady, D. (1985). Den dolda läroplanen (4. uppl.). Lund: Symposium.

Callewaert, S. \& Nilsson, B. (1977). Sambället, skolan och skolans inre arbete. Lund: Lunds bok och tidskrifts AB.

Carlgren, I. (1986). Lokalt utvecklingsarbete (Doktorsavhandling). Göteborg: Acta Universitatis Gothoburgensis. 
Carlgren, I. (1996). Lärarutbildning som yrkesutbildning. I: Ds 1996:16. Lärarutbildning i förändring. Stockholm: Fritzes.

Carlgren, I. \& Hörnqvist, B. (1999). När inget facit finns. Om skolutveckling i en decentraliserad skola. Stockholm: Statens skolverk.

Carlgren, I., Josefson, I. \& Liberg, C. (2005). Forskning av denna världen II. Om teorins roll i praxisnära forskning. Stockholm: Vetenskapsrådet.

Dahllöf, U. (1989). Nyckelproblem i den svenska pedagogikens utveckling. Forskning om utbildning.16(4), 4-20.

Ds 1996:16. Lärarutbildning i förändring. Stockholm: Fritzes.

Florin, C. (1987). Kampen om katedern: feminiserings- och professionaliseringsprocessen inom den svenske folkskolans lärarkiar 1860-1906 (Doktorsavhandling). Umeå: Acta universitatis Umensis.

Hattie, J. (2008). VisiblelLearning: A synthesis of over 800 meta-analyses relating to achievement. Routledge: Abingdon.

Hermansson, E. (1974). Upplevelser och påverkan: jämförelsematerial för pedagogiskt intresserade. Stockholm: Sveriges lärarförbund.

Härnqvist, K. (1958). Beräkning av reserver för högre utbildning. I SOU 1958:11. 1955 àrs universitets utredning. 3, Reserverna för högre utbildning: beräkningar och metoddiskussion (s. 7-92).

Husén, T. (1948). Begåvning och miljö. Studier i begånningsutvecklingens och begånningsurvalets psykologisk-pedagogiska och sociala problem. Stockholm: Gebers.

Jordell, K. Ø. (1986). Fra pult til kateter. Om socialisering i lareryrket. D. 1. Tromsö: Tromsö universitet.

Kuhn, T.(1962. The structure of scientific revolutions. Chicago: Univ. of Chicago Press.

Landahl, J. (2015). Det nordiska skolmötet som utbildningspolitisk arena. Ett rumsligt perspektiv på den moderna pedagogikens historia. Utbildning och demokrati, 24(3), 7-23.

Lesche, C. (1972). Vetenskapsteoretiska synpunkter på psykiatri. Nordisk, psykiatrisk tidskrift, 26(2), 59-79.

Popkewitz, T. (1997). A changing terrain of knowledge and power: A social epistemology of educational research. Educational Researcher, 26(9), 18-29.

Rosengren, K-E. \& Öhngren, B. (Red.) (1997). An evaluation of Swedish research in education. Stockholm: HSFR.

Sandström, B. \& Ekholm, M. (1984). Stabilitet och förändring i skolan. Stockholm: Liber utbildningsförl.

Skogstad, I. (2018, 7/1). Henrekson: Pedagogerna tiger ihjäl kritiken. Göteborgsposten. Hämtad från: http://www.gp.se/ledare/henrekson-pedagogerna-tiger-ihjälkritiken-1.4950513 
SOU 1948:27. 1946 års skolkommissions betänkande med förslag till riktlinjer för det svenska skolväsendets utveckling. Stockholm: Ecklesiastikdepartementet.

SOU 1952:33. Den första Lärarbögskolan. Stockholm: Ecklesiastikdepartementet.

SOU 1965:29. 1960 års lärarutbildningssakekuniga. 4. Lärarutbildningen, 1. Stockholm: Ecklesiastikdepartementet.

SOU 1978:86. Lärare för skola i utveckling. Betänkande av 1974 års lärarutbildningsutredning. Stockholm: Allmänna förl.

SOU 1980:2. Skolforskning och skolutveckling. Betänkande av Skolforskningskommittén. Stockholm: Allmänna förl.

SOU 1999:63. Att lära och leda. En lärarutbildning för samverkan och utbildning. Stockholm: Fakta info direkt.

SOU 2008:109. En hållbar lärarutbildning. Betänkande av Utredningen om en ny lärarutbildning. Stockholm: Fritzes.

SOU 2017:35. Samling för skolan. Nationell strategi för kunskap och likvärdighet. Stockholm: Wolters Kluwer.

SOU 2018:19. Forska tillsammans. Samverkan för lärande och förbättring. Stoxkholm: Nordsteds juridik.

Ödman, P-J. (1979). Tolkning, förståelse, vetande: hermeneutik $i$ teori och praktik. Stockholm: AWE/Geber. 